\title{
単為結果性トマトの種子形成に及ぼす交配親および交配時期の影響
}

\author{
大川浩司 $* \mathrm{a} \cdot$ 菅原眞治 ${ }^{\mathrm{b}} \cdot$ 矢部和則 \\ 愛知県農業総合試験場４80-1193＼cjkstart愛知県愛知郡長久手町
}

\section{Effects of Crossing Parents and Artificial Crossing Stage on Seed Development of Parthenocarpic Tomato}

\author{
Hiroshi Ohkawa*a, Shinji Sugahara ${ }^{\mathrm{b}}$ and Kazunori Yabe \\ Aichi-ken Agricultural Research Center, Nagakute-cho, Aichi 480-1193
}

\begin{abstract}
To identify factors involved in seed development of parthenocarpic tomato, the effects of combinations of crossing parents and crossing stage on seed development of parthenocarpic tomato were examined. And the ovary size of parthenocarpic tomato before and after the flowering stage was compared with that of non-parthenocarpic tomato. When the seed parent was the nonparthenocarpic tomato cultivar 'Momotaro york', the seeded fruit rate was $100 \%$ irrespective of the pollen parent, there were about two hundred seeds per fruit. When the seed parent was the parthenocarpic tomato pure bred strain 'PASK-1' or 'PF$811 \mathrm{~K}$ ', the seeded fruit rate was $72 \sim 94 \%$ irrespective of the pollen parent, there were $7.6 \sim 29.9$ seeds per fruit. Therfore, it was suggested that seed development of parthenocarpic tomato was affected by the seed parent irrespective of the pollen parent, and seeds were apt to remain undeveloped when the seed parent was parthenocarpic. Concerning artificial crossing stage on seed development of parthenocarpic tomato, the seeded fruit rate of non-parthenocarpic tomato cultivar 'Momotaro york' was $100 \%$ irrespective of artificial crossing stage, and the numbers of seeds per fruit of 'Momotaro york' remained standard. The seeded fruit rate of 'Renaissance' two days after flowering was $8 \%$ in spring and $33 \%$ in autumn. Those values were very low compared with $96 \%$ in spring and $87 \%$ in autumn on flowering. And the numbers of seeds per fruit of 'Renaissance' were as few as 0.8 in spring and 4.0 in autumn. Furthermore, the ovary of 'Renaissance' from bud stage to two days after flowering enlarged successively in length and breadth. Accordingly it was suggested that the decline of seed development faculty of the parthenocarpic tomato cultivar 'Renaissance' by two days after flowering was not influenced by the decline of fertilization faculty of pistil, but the expression of parthenocarpy before flowering.
\end{abstract}

Key Words : flowering, ovary, seeded fruit

キーワード：開花，子房，有種子果

\section{緒言}

合成ホルモン剂処理や訪花昆虫による受粉を必要としな い単為結果性トマトは，省力化と低コスト化が期待できる ことから農家の関心が高い，我が国では，近年になってロ シアのトマト品種 ‘Severianin’ 由来の単為結果性遺伝子 pat-2 (Philouze・Maisonneuve, 1978a, b) の導入により, 1994 年に初めての実用的な単為結果性品種として ラークナ ファースト’（菅原ら，1995）が，2000年には完熟収穫型 の ‘ルネッサンス’（菅原ら，2002）が育成された。“ルネッ サンス’ は, 春, 夏, 秋および冬のいずれの季節でも着果

2007 年 10 月 26 日 受付. 2007 年 12 月 27 日 受理.

本報告の一部は, 園芸学会平成 17 年度春季大会で発表した.

* Corresponding author. E-mail: hiroshi_ookawa@pref.aichi.lg.jp

a 現在 : 愛知県農業総合試験場園芸研究部（弥富）498-0003 愛 知県弥富市

b 現在 : 愛知県日進市
率が非常に高く，発育不良果の発生もみられず，単為結果 性の発現が安定していること（大川ら，2006），日最高気温 の平均值が $39.2^{\circ} \mathrm{C}$ の高温や日最低気温の平均值が $5.9^{\circ} \mathrm{C}$ の 低温のよらな環境ストレス条件下でも優れた着果性と安定 した果実肥大性を発揮すること（大川ら，2007）から，一 般的な非単為結果性トマトに比べて生産性の向上が可能で あることが明らかにされている。しかしながら，単為結果 性トマトの $\mathrm{F}_{1}$ 採種時に打忊る種子生産量は, 非単為結果性 トマトに比べて少なく，かつ，安定していない，そのため， 採種労力や種子生産コストが通常の $\mathrm{F}_{1}$ 品種より多く必要と なり，単為結果性トマトの栽培を普及するらえでの問題と なっている. そこで，単為結果性トマトの種子形成に関与 する要因を明らかし，採種効率を向上させるため，本研究 では交配親の組み合わせ扣よび交配時期が単為結果性トマ トの種子形成に及ぼす影響を検討した。また，種子形成に 及ぼす交配時の子房の影響についてみるため, 開花の前後 に拈ける子房の大きさの変化について，単為結果性トマト 
と非単為結果性トマトの品種比較を行った.

\section{材料および方法}

\section{試験 1. 交配親の組み合わせが種子形成に及ぼす影響}

供試材料は, 単為結果性 $F_{1}$ 品種 ‘ルネッサンス’ の母親 系統 'PASK-1' (単為結果性, 固定系統), 父親系統 'PF811K' (単為結果性, 固定系統) 抢上び ‘桃太郎ヨーク’ (非単為 結果性， $F_{1}$ 品種）の 3 品種・系統で，それぞれを種子親ま たは花粉親とする 9 組久合わせの交配を行った．種子親は 開花前に除雄し, 開花時に当日開花した花粉親の花粉を交 配した。な拉，開花は花弁が完全に外側に展開し，花弁の 色が最も黄味を帯びた時とした. 3 品種・系統とも， 2004 年 4 月 1 日に播種， 5 月 5 日に隔離ベッドに定植し，複合 液肥（OK-F-2, 14-8-16）を用いて養液土耕栽培を行った. 種子親が ‘PASK-1' と 'PF811K' では第 1 花房と第 2 花房 を，“桃太郎ヨーク’では他 2 系統よりも開花が早かったた めに第 1 花房は切除して第 2 花房と第 3 花房を用いた。種 子親が 'PASK-1' と 'PF811K' では第 2 花房上の 2 葉を 残し, “桃太郎ヨーク’ では第 3 花房上の 2 葉を残して摘心 した. 花房当たりの処理花数は 3 花で，その他の花はすべ て除去し，1組み合わせ当たり 18 果を調查した. 換気温度 は $28^{\circ} \mathrm{C}$ ，最低温度は $15^{\circ} \mathrm{C}$ で管理した。

\section{試験 2. 交配時期が種子形成に及ぼす影響}

供試材料は, 単為結果性 $F_{1}$ 品種の ‘ルネッサンス’, 非 単為結果性 $F_{1}$ 品種の ‘桃太郎ヨーク’ とした。 ‘ルネッサン ス’ $\mathrm{F}_{1}$ 品種であるが，母親系統 'PASK-1' 抢よび父親 系統 'PF811K' と同様に劣性の単為結果性遺伝子 pat-2 を ホモに持つ（菅原ら，2002）ことから材料として選択した. 両品種とも, 交配時期を蕾時 (開花 $2 \sim 3$ 日前を目標), 開 花時, 開花 2 日後とする 3 処理区を設けた。 いずれも開花 前に除雄し, 所定の交配時期に当日開花した同一品種の花 粉を交配した. 試験は, 春季と秋季の 2 回行った. 春季試
験では，2004 年 4 月 1 日に播種，5月 5 日に 7 号ポットに 定植し，複合液肥（OK-F-2, 14-8-16）を用いて養液土耕栽 培を行った。換気温度は $28^{\circ} \mathrm{C}$, 最低温度は $15^{\circ} \mathrm{C}$ で管理し, 2 段摘心栽培とした．花房当たりの処理花数は 3 花で，そ の他の花はすべて除去し，1 組久合わせ当たり 24 果を調査 した. 秋季試験では，2004 年 9 月 3 日に播種，9月 13 日に 3.5 号ポットに鉢上げし，10 月 6 日に地床に定植した. 3 段 摘心栽培の第 1 花房を供試し， 1 組み合わせ当たり 15 果を 調查した．第2，第3 花房については“ルネッサンス’は 放任とし，“桃太郎ヨーク’は 4-chlorophenoxy acetic acid 液 $\left(15 \mathrm{mg} \cdot \mathrm{L}^{-1}\right)$ の処理を行って着果させた。 その他の耕種概 要は春季試験と同様とした。

\section{試験 3. 開花の前後における子房の大きさの変化}

供試材料は試験 2 と同様とした。調查時期は両品種とも 蕾時 (開花 $2 \sim 3$ 日前を目標), 開花時, 開花 2 日後の 3 回 とした. 各時期に花を摘除し, 花から花弁と葯を分離して, 子房の横径扣よび縦径をデジタルノギスで測定した.なお， 両品種とも開花時と開花 2 日後に調査寸る子房は, 受精に よる肥大を防ぐため予め蕾時に除雄した. 2004 年 9 月 3 日 に播種，9月 13 日に 3.5 号ポットに鉢上げし，10月 6 日に 地床に定植した. 2 段摘心栽培とし， 1 花房当たり 4 花に制 限して, 各区当たり 16 花を調査した。 その他の耕種概要は 試験 2 の秋季と同様とした.

\section{結 果}

\section{試験 1. 交配親の組み合わせが種子形成に及ぼす影響}

交配親の組久合わせが，着果率，有種子果率，1果重打 よび種子数に及ぼす影響を第 1 表に示した。着果率は，1 組久合わせ ('PF811K' × 'PASK-1') を除きいずれも100\% であった，有種子果率は，“桃太郎ヨーク’を種子親とした 場合には花粉親の種類に関係なくいずれも100\%であった. ‘PASK-1’を種子親とした場合，花粉親が ‘PASK-1’では

第 1 表 単為結果性および非単為結果性を異にした交配親の組み合わせが着果率, 有種子果率, 1 果重および種子数に及ぼす影響

\begin{tabular}{|c|c|c|c|c|c|c|}
\hline 種子親 & & 花粉親 & 着果率 ${ }^{\mathrm{z}}(\%)$ & 有種子果率y（\%) & 1 果重（g） & 種子数 (粒/果 $\left.{ }^{\mathrm{x}}\right)$ \\
\hline \multirow{3}{*}{ PASK-1 } & \multirow{3}{*}{$x$} & PASK-1 & 100 & 72 & $214 \pm 15^{w}$ & $27.9 \pm 12.1^{\mathrm{w}}$ \\
\hline & & PF811K & 100 & 89 & $221 \pm 12$ & $15.5 \pm 4.6$ \\
\hline & & 桃太郎ヨーク & 100 & 78 & $214 \pm 16$ & $7.6 \pm 2.5$ \\
\hline \multirow{3}{*}{ PF811K } & \multirow{3}{*}{$x$} & PASK-1 & 94 & 94 & $267 \pm 15$ & $22.4 \pm 5.8$ \\
\hline & & PF811K & 100 & 89 & $263 \pm 8$ & $18.7 \pm 4.2$ \\
\hline & & 桃太郎ヨーク & 100 & 94 & $262 \pm 10$ & $29.9 \pm 4.4$ \\
\hline \multirow{3}{*}{ 桃太郎ヨーク } & \multirow{3}{*}{$x$} & PASK-1 & 100 & 100 & $238 \pm 16$ & $183.2 \pm 17.1$ \\
\hline & & PF811K & 100 & 100 & $247 \pm 11$ & $210.6 \pm 11.4$ \\
\hline & & 桃太郎ヨーク & 100 & 100 & $267 \pm 11$ & $175.4 \pm 15.9$ \\
\hline
\end{tabular}

PASK-1：単為結果性固定系統（単為結果性 $\mathrm{F}_{1}$ 品種 ‘ルネッサンス’ の母親系統）

PF811K : 単為結果性固定系統 (単為結果性 $\mathrm{F}_{1}$ 品種 ‘ルネッサンス’ の父親系統)

桃太郎ヨーク : 非単為結果性 $\mathrm{F}_{1}$ 品種

$\mathrm{z}$ 着果数 $/$ 開花数 $\times 100$

$\mathrm{y}$ 有種子果数 / 着果数 $\times 100$

$\mathrm{x}$ 着果数

$\mathrm{w}$ 平均 $\pm \mathrm{SE}(\mathrm{n}=17 \sim 18)$ 
72\%，“PF811K’ では 89\%，“桃太郎ヨーク’では 78\%の有

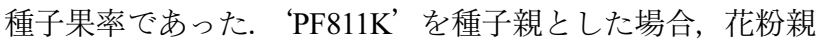
が 'PASK-1' では 94\%, 'PF811K' では 89\%，“桃太郎ヨー ク’では 94\%の有種子果率であった， 1 果重は，種子親が 同一の場合, 花粉親の違いによる影響はみられなかった. 1 果当たりの種子数は, ‘PASK-1’を種子親とした場合, 花 粉親が ‘PASK-1’では 27.9 粒, ‘PF811K’では 15.5 粒, ‘桃 太郎ヨーク’では 7.6 粒であった。 ‘PF811K’を種子親と した場合, 花粉親が ‘PASK-1' では22.4 粒, ‘PF811K’ で は 18.7 粒，“桃太郎ヨーク’では29.9 粒であった。一方, “桃太郎ヨーク’を種子親とした場合, 花粉親が 'PASK-1' では 183.2 粒, ‘PF811K’ では210.6 粒, ‘桃太郎ョーク’ では 175.4 粒と, いずれの花粉親との組み合わせも前記 2 系統を種子親とする場合に比べて明らかに多かった.

\section{試験 2. 交配時期が種子形成に及ぼす影響}

春季に打ける交配時期が, 着果率, 有種子果率, 1 果重 および種子数に及ぼす影響を第 2 表に示した. 開花 $2 \sim 3$ 日前を目標にした蕾時の交配時期は, ‘ルネッサンス’が開
花 2.8 日前，“桃太郎ヨーク’ が開花 2.3 日前であった．着 果率は, 両品種ともいずれの交配時期でも $96 \%$ 以上であっ た. 有種子果率は“桃太郎ヨーク’がいずれの交配時期で も100\%であったのに対し，“ルネッサンス’ は蕾時と開花 時では96\%であったが, 開花 2 日後では $8 \%$ と著しく低かっ た. 1 果重は，両品種とも交配時期による差異はみられな かった. 1 果当たりの種子数は，“桃太郎ヨーク’ が開花時 218.5 粒, 開花 2 日後 100.4 粒, 蕾時 81.0 粒の順であった が, ‘ルネッサンス’ は蕾時が 40.9 粒, 開花時が 38.3 粒で, 有種子果率の低かった開花 2 日後は 0.8 粒であった.

秋季に打社配時期が，着果率，有種子果率，1 果重 および種子数に及ぼす影響を第 3 表に示した. 開花 $2 \sim 3$ 日前を目標にした蕾時の交配時期は，“ルネッサンス’が開 花 2.5 日前, ‘桃太郎ヨーク’ が開花 2.8 日前であった. 着 果率は, 両品種ともいずれの交配時期でも $100 \%$ であった. 有種子果率は“桃太郎ヨーク’がいずれの交配時期でも 100 \%であったのに対し，“ルネッサンス’は蕾時では 100\%, 開花時では $87 \%$, 開花 2 日後では 33\%であった. 1 果重は,

第 2 表 春季における単為結果性および非単為結果性トマトの交配時期が着果率，有種子果率，1 果重および種子数に及ぼす影響

\begin{tabular}{|c|c|c|c|c|c|}
\hline 品種 & 交配時期 & 着果率z（\%） & 有種子果率 ${ }^{\mathrm{y}}(\%)$ & 1 果重（g） & 種子数 (粒/果 $\left.{ }^{\mathrm{x}}\right)$ \\
\hline \multirow{3}{*}{ ルネッサンス } & 蕾時v & 96 & 96 & $148 \pm 8^{w}$ & $40.9 \pm 6.2^{\mathrm{w}}$ \\
\hline & 開花時 & 100 & 96 & $164 \pm 9$ & $38.3 \pm 5.9$ \\
\hline & 開花 2 日後 & 100 & 8 & $163 \pm 10$ & $0.8 \pm 0.6$ \\
\hline \multirow{3}{*}{ 桃太郎ヨーク } & 蕾時 u & 96 & 100 & $154 \pm 9$ & $81.0 \pm 11.4$ \\
\hline & 開花時 & 100 & 100 & $183 \pm 7$ & $218.5 \pm 10.6$ \\
\hline & 開花 2 日後 & 96 & 100 & $178 \pm 12$ & $100.4 \pm 11.7$ \\
\hline
\end{tabular}

ルネッサンス：単為結果性 $\mathrm{F}_{1}$ 品種

桃太郎ヨーク : 非単為結果性 $\mathrm{F}_{1}$ 品種

$\mathrm{z}$ 着果数 /開花数 $\times 100$

$\mathrm{y}$ 有種子果数 / 着果数 $\times 100$

$\mathrm{x}$ 着果数

$\mathrm{w}$ 平均 $\pm \mathrm{SE}(\mathrm{n}=23 \sim 24)$

$\mathrm{v}$ 開花 2.8 日前

u開花 2.3 日前

第 3 表 秋季に抢ける単為結果性扎よび非単為結果性トマトの交配時期が着果率，有種子果率，1 果重招よび種子数に及ぼす影響

\begin{tabular}{|c|c|c|c|c|c|}
\hline 品種 & 交配時期 & 着果率z（\%） & 有種子果率 ${ }^{\mathrm{y}}(\%)$ & 1 果重（g） & 種子数 (粒 $/$ 果 $\mathrm{x})$ \\
\hline \multirow{3}{*}{ ルネッサンス } & 蕾時v & 100 & 100 & $168 \pm 4^{\mathrm{w}}$ & $35.7 \pm 6.5^{\mathrm{w}}$ \\
\hline & 開花時 & 100 & 87 & $165 \pm 6$ & $51.1 \pm 8.0$ \\
\hline & 開花 2 日後 & 100 & 33 & $173 \pm 5$ & $4.0 \pm 2.3$ \\
\hline \multirow{3}{*}{ 桃太郎ヨーク } & 蕾時 u & 100 & 100 & $160 \pm 11$ & $138.8 \pm 16.0$ \\
\hline & 開花時 & 100 & 100 & $170 \pm 11$ & $179.4 \pm 15.6$ \\
\hline & 開花 2 日後 & 100 & 100 & $170 \pm 12$ & $145.1 \pm 17.5$ \\
\hline
\end{tabular}

ルネッサンス：単為結果性 $\mathrm{F}_{1}$ 品種

桃太郎ヨーク : 非単為結果性 $\mathrm{F}_{1}$ 品種

$\mathrm{z}$ 着果数 $/$ 開花数 $\times 100$

$\mathrm{y}$ 有種子果数 /着果数 $\times 100$

$\mathrm{x}$ 着果数

$\mathrm{w}$ 平均 $\pm \mathrm{SE} \quad(\mathrm{n}=15)$

$\mathrm{v}$ 開花 2.5 日前

$\mathrm{u}$ 開花 2.8 日前 

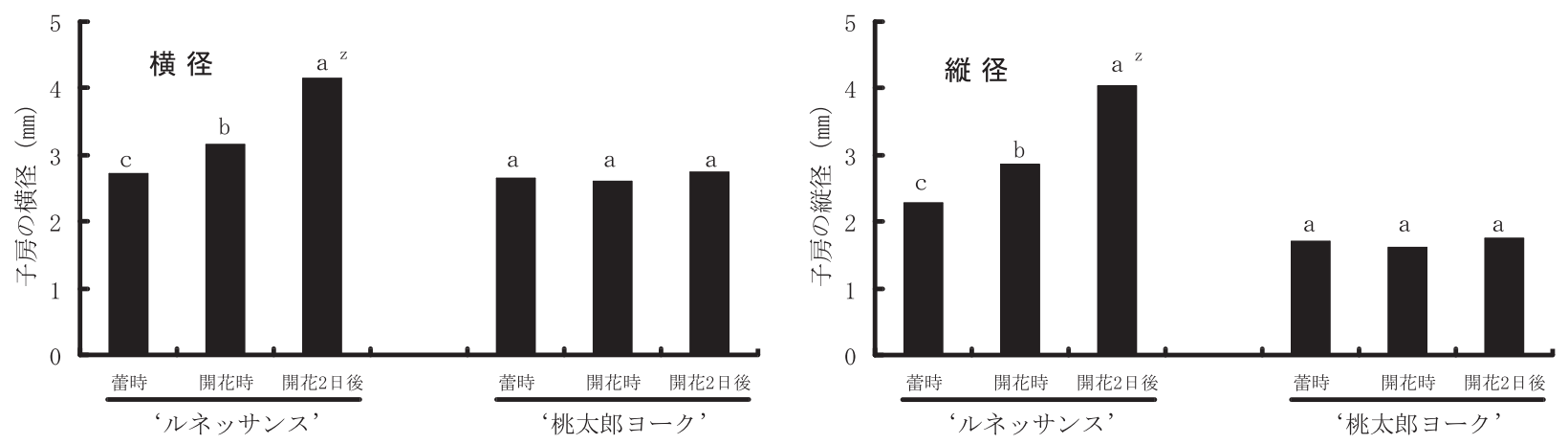

第 1 図 開花の前後に拈ける単為結果性および非単為結果性トマトの子房の横径および縦径の変化 ルネッサンス: 単為結果性 $\mathrm{F}_{1}$ 品種 桃太郎ヨーク : 非単為結果性 $\mathrm{F}_{1}$ 品種 $\mathrm{z}$ 同一品種内の異なるアルファベット間には 5\%水準で有意差あり（Tukey-Kramer test）

両品種とも交配時期による差異はみられなかった。 1 果当 たりの種子数は, ‘桃太郎ヨーク’が蕾時 138.8 粒, 開花時 179.4 粒, 開花 2 日後 145.1 粒であったが, ‘ルネッサンス’ は蕾時 35.7 粒, 開花時 51.1 粒で, 有種子果率の低かった開 花 2 日後は 4.0 粒であった.

\section{試験 3. 開花の前後における子房の大きさの変化}

子房の横径は, ‘ルネッサンス’ では蕾時 $2.73 \mathrm{~mm}$, 開花 時 $3.16 \mathrm{~mm}$, 開花 2 日後 $4.14 \mathrm{~mm}$ と時間の経過に伴って増 加したのに対し, ‘桃太郎ヨーク’ では蕾時 $2.65 \mathrm{~mm}$, 開花 時 $2.60 \mathrm{~mm}$, 開花 2 日後 $2.75 \mathrm{~mm}$ と変化はなかった. 子房 の縦径も, ‘ルネッサンス’ では蕾時 $2.27 \mathrm{~mm}$, 開花時 $2.85 \mathrm{~mm}$, 開花 2 日後 $4.04 \mathrm{~mm}$ と時間の経過に伴って増加 したのに対し，“桃太郎ヨーク’では蕾時 $1.70 \mathrm{~mm}$, 開花時 $1.62 \mathrm{~mm}$, 開花 2 日後 $1.76 \mathrm{~mm}$ と変化はなかった (第 1 図).

\section{考察}

我が国の実用的な $\mathrm{F}_{1}$ 品種の採種では，1 果当たり 200 粒 程度（関口，1988）の種子が生産される. 本研究での交配 親の組み合わせにおいても，種子親を非単為結果性品種の “桃太郎ヨーク’ とした場合, 花粉親の種類にかかわらず有 種子果率は $100 \%$ で, 1 果当たりの種子数は 200 粒前後と標 準的であった。 しかし，種子親を単為結果性固定系統の 'PASK-1'打よび ‘PF811K' とした場合, 花粉親にかかわ らず, 有種子果率は $75 \sim 94 \%$ とやや低くなり，1 果当たり の種子数は $7.6 \sim 29.9$ 粒で, 種子親を ‘桃太郎ヨーク’ と した場合に比べて明らかに少なかった。交配する季節なら びに花 (花蕾) 処理が ‘ルネッサンス’ の着果预よび果実 特性に及ぼす影響を検討した既往の報告（大川ら，2006） でも, ‘ルネッサンス’の振動受粉に打ける 1 果当たりの種 子数は, 春季が 23.9 粒, 秋季が 19.0 粒で, 本研究に抢ける 種子親を 'PASK-1' および ‘PF811K' とした場合と同等 で少なかった。これらの季節は, 本来, 受精に適した気候 条件と推測され，実際に同様な栽培条件下での振動受粉に よる ‘桃太郎ョーク’の 1 果当たり種子数は, 春季が 179.4 粒, 秋季が 245.0 粒と標準的であった。 また, 本研究では
最低温度を $15^{\circ} \mathrm{C}$ で管理したことから，雄ずいの花粉稔性 低下による受精能力の欠如（藤下，1970）が種子形成の少 ない要因とは考光にくい，従って，単為結果性トマトの種 子形成には, 単為結果性の有無による花粉親の種類は関係 がなく, 種子親の種類が大きく関与し, 種子親が単為結果 性の場合に種子は形成されにくくなると推察された.

次に, 交配時期と単為結果性卜マトの種子形成の関係を みると, 春季打よび秋季とも非単為結果性品種の“桃太郎 ヨーク’は，交配時期にかかわらず有種子果率はいずれる 100\%であった． 1 果当たりの種子数は，秋季では交配時期 による差異は久られず 150 粒前後であり, 春季では開花時 が 218.5 粒と最も多く, 以下, 開花 2 日後の 100.4 粒, 蕾時 （開花 2.3 日前）の 81.0 粒の順であった. トマトは，雌ずい の受精能力が長く維持され，開花後 $3 \sim 4$ 日あることが採 種経験上知られて和り (阿部, 1978), これは本研究の結果 とほぼ一致する．当然，季節による雌ずいの受精能力保持 期間の差異はあると推測されるが, 開花後直ちに受精能力 が低下することはないと考兄られる。また，“桃太郎ヨー ク’では受精が行われなければ, 開花の前後で子房の大き さの変化は久られない，一方，“ルネッサンス’では, 蕾時 から開花 2 日後にかけて子房は横径敃よび縦径とも順次増 加していることから，単為結果性の発現は開花前にはすで に始まっていると考它られる。また, ‘ルネッサンス’の有 種子果率は, 開花 2 日後では春季が $8 \%$, 秋季が $33 \%$ と, 開花時での春季 $96 \%$, 秋季 $87 \%$ に比べて大きく低下し，1 果当たりの種子数も開花 2 日後では春季が 0.8 粒, 秋季が 4.0 粒と極端に少なかった。 これらのことから，“ルネッサ ンス’の開花 2 日後に打ける種子数の減少は雌ずいの受精 能力低下の影響ではなく, 開花前からの単為結果性の発現 による影響と推察される。単為結果性トマトでは, 果実胚 珠内の偽胚の発達と果実肥大に同調性がみられ（Kataoka ら，2003）, 開花直後にジベレリン活性が増加すること (Mapelli ら, 1978), 偽肧発達は内生ジベレリンによるコン トロールの可能性があること（片岡，2004）が報告されて いる。 また，オーキシンによるジベレリン生合成の制御や 
ジベレリン情報伝達経路の制御が分子レベルで明らかにさ れつつある(山口, 2004). 従って今後は, 開花前からのジ ベレリン，オーキシンなどの内生植物成長調節物質の制御 が種子形成に及ぼす影響について検討する必要がある. 開 花の前後に打ける子房の大きさの変化から，“ルネッサン ス’ は開花前の段階から子房が肥大することが明らかに なったが，子房肥大中である開花時の交配でも蕾時（開花 $2 \sim 3$ 日前）と同等の 1 果当たり約 40 粒の種子が得られ， 種子数が大幅に減少したのは開花 2 日後で, 子房の肥大開 始時期と種子数の減少時期に時間的なずれが認められた. ただし, 蕾時と開花時の交配に打ける 1 果当たり 40 粒前後 の種子数は，一般的な非単為結果性品種の $1 / 5$ 程度と少な く採種効率は依然低い. 子房肥大時期が開花 $2 \sim 3$ 日前よ りさらに前であるかは, 本研究の結果からは判断はできな いことから, 今後, 様々な条件下に打ける子房肥大の開始 時期の把握と, 子房の肥大状況を異にした場合における受 精が種子形成に及ぼす影響について検討することも, 採種 効率向上のために重要と考えられる.

\section{摘 要}

単為結果性トマトの種子形成に関与する要因を明らかに するため, 交配親の組み合わせおよび交配時期が単為結果 性トマトの種子形成に及ぼす影響について検討した. また, 開花の前後に打敌房の大きさの変化について, 単為結 果性トマトと非単為結果性トマトの品種比較を行った. 種 子親を非単為結果性品種の ‘桃太郎ヨーク’とした場合, 花粉親の種類にかかわらず有種子果率は $100 \%$ で, 1 果当た りの種子数は 200 粒前後であった. 種子親を単為結果性固 定系統の ‘PASK-1' 拉よび ‘PF811K' とした場合, 花粉 親の種類にかかわらず，有種子果率は $72 \sim 94 \%$ とやや低 く, 1 果当たりの種子数は $7.6 〜 29.9$ 粒であった. 従って, 単為結果性トマトの種子形成には, 花粉親の種類は関係が なく, 種子親の種類が大きく関与し, 種子親が単為結果性 の場合に種子は形成されにくくなると推察された。交配時 期が単為結果性トマトの種子形成に及ぼす影響について は, 非単為結果性品種の ‘桃太郎ヨーク’ は, 交配時期に かかわらず有種子果率はいずれも $100 \%$ であり，1 果当たり の種子数も標準的であった。一方，単為結果性品種の“儿 ネッサンス’の有種子果率は, 開花 2 日後では春季が $8 \%$, 秋季が $33 \%$ と, 開花時での春季 96\%, 秋季 $87 \%$ に比べて 大きく低下し， 1 果当たりの種子数も開花 2 日後では春季 が 0.8 粒, 秋季が 4.0 粒と極端に少なかった. また, 蕾時か ら開花 2 日後にかけて ‘ルネッサンス’の子房は, 横径お よび縦径とも順次増加した. 従って, ‘ルネッサンス’の開 花 2 日後に扣ける種子形成能力の低下は, 雌ずいの受精能 力低下ではなく, 開花前からの単為結果性の発現による影 響と推察された.

\section{引用文献}

阿部秀二. 1978. トマト $\mathrm{F}_{1}$ の採種技術. p. 243-250. そ菜 種子生産研究会編. 野菜の採種技術. 誠文堂新光社. 東京.

藤下典之. 1970. 各種蔬菜における低温, 高温, 暗黒, 除 雄剤などの処理にもとづく花粉退化とその機構に関す る研究. 大阪府大紀 (農・生). 22: 111-208.

Kataoka, K., A. Uemachi and S. Yazawa. 2003. Fruit growth and pseudoembryo development affected by uniconazole, an inhibitor of gibberellin biosynthesis, in pat-2 and auxininduced parthenocarpic tomato fruits. Sci. Hort. 98: 9-16.

片岡圭子．2004.トマトに打ける単為結果果実の誘導およ び発達に関する研究. 生長調節物質の関与と偽肧形成. 京都大学学位論文.

Mapelli, S., C. Frova, G. Torti and G. P. Soressi. 1978. Relationship between set, development and activities of growth regulators in tomato fruits. Plant Cell Physiol. 19: 1281-1288.

大川浩司・菅原眞治・高市益行・矢部和則. 2007. 高温抒 よび低温条件下に打戦為結果性トマト‘ルネッサ ンス’の着果および果実肥大特性. 園学研. 6: 449-454.

大川浩司・菅原眞治・矢部和則. 2006. 時季および花（花 蕾) の処理が単為結果性トマト品種 ‘ルネッサンス’の 着果抏よび果実特性に及ぼす影響. 園学研. 5: 111-115.

Philouze, J. and B. Maisonneuve. 1978a. Heredity of the natural ability to set parthenocarpic fruits in the soviet variety Severianin. Tomato Genet. Coop. Rep. 28: 12-13.

Philouze, J. and B. Maisonneuve. 1978b. Breeding tomatoes for their ability to set fruit at low temperatures. p. 54-64. In: Breeding Proc. Eucarpia Tomato Working Group (ed.). Genotype and Environment in Glasshouse Tomato. Leningrad, USSR.

関口 勲. 1988. 採種栽培に打ける施設利用. トマト。 p. 349-357. そ菜種子生産研究会編. 八イテクによる野菜 の採種. 誠文堂新光社. 東京.

菅原眞治・榎本真也・大藪哲也・矢部和則・野口博正. 2002. 完熟収穫型単為結果性トマト品種 ‘ルネッサンス’の 育成経過と特性. 愛知農総試研報. 34: 37-42.

菅原眞治・坂森正博・青柳光昭. 1995. 温室卜マトへの単 為結果性因子の導入（第 3 報）単為結果性卜マト新品 種「ラークナファースト」の育成. 愛知農総試研報. 27: $167-173$.

山口信次郎. 2004. オーキシンとジベレリンのクロストー ク. p. 97-99. 福田裕穂・町田泰則・神谷勇治・柿本辰 男監修. 新版植物ホルモンのシグナル伝達. 秀潤社. 東京. 